\title{
Archaeology and Zooarchaeology of the Late Iron Age-Roman Transition in the Province of Raetia (100 BC-100 AD)
}

\author{
Simon Trixl ${ }^{1}$, Bernd Steidl ${ }^{2}$ and Joris Peters ${ }^{3}$ \\ ${ }^{1}$ Ludwig Maximilian University, Munich, Germany \\ ${ }^{2}$ Bavarian State Archaeological Collection, Munich, Germany \\ ${ }^{3}$ Ludwig Maximilian University, Munich, and Bavarian State Collection for \\ Anthropology and Palaeoanatomy, Munich, Germany
}

\begin{abstract}
The incorporation of the region north of the Alpine divide and its foreland into the Imperium Romanum initiated major changes in economic and social structure and in everyday life in the newlyfounded province of Raetia. Controversy exists, however, about the continuity of local La Tène traditions into early Roman times, since the archaeological evidence recorded to date tends to give the impression that the northern Alpine foreland was largely unpopulated at the time of the Roman conquest in 15 BC. However, ongoing excavations in this region are gradually enhancing the archaeological visibility of this transitional phase. Compared to early Roman provincial populations settled along the Via Claudia Augusta and its hinterland, a culturally unique community stands out: the Heimstetten group. This group is located in the eastern Raetian hinterlands and dates to around 30-60 AD. Its building tradition, settlement structure, and burial customs show close affinities with the La Tène culture, thus suggesting continuity in autochthonous culture at the time of the early Roman occupation. Since faunal remains can potentially act as cultural markers, additional insights can be gained from a spatial-temporal analysis of livestock composition and breeding practices. The results presented here clearly show that, during the Iron Age, marked regional differences in species composition are visible, implying the possibility of distinct developments during early Romanization. In addition to evaluating faunal developments in the study area between c. $100 \mathrm{BC}-100 \mathrm{AD}$, the issue of cattle breeding-traditionally the mainstay of livestock economies in many regions and especially in the Munich Gravel Plain at least since the Bronze Age-is addressed in greater detail.
\end{abstract}

Keywords: Raetia, Iron Age, Late Iron Age to Roman transition, Heimstetten group, Romanization, livestock composition, cattle

\section{INTRODUCTION}

The Roman military occupation of the central European Alpine region and its northern foreland in $15 \mathrm{BC}$ represents one of the most historically significant incursions into the cultural development of this area. Socio-cultural structures as well as subsistence and everyday life witnessed fundamental changes under the influence of the novel Mediterranean lifestyle. So far, however, the issue of continuity of Celtic lifeways into Roman times could not be answered conclusively. Until recently, archaeological evidence for the presence of an autochthonous population in the decades before and after the initial Roman occupation was almost non-existent. As a result, it was postulated that the area was mostly uninhabited before the 
onset of Roman occupation (e.g. Sommer, 2008). But archaeological finds uncovered recently from settlements dating to the last century preceding the Roman occupation (e.g. Meixner \& Pütz, 2013), and excavations of burials and settlements of the socalled Heimstetten group (c. AD 30-60) in particular (e.g. Volpert \& Früchtl, 2012), revealed building traditions and artefacts possibly indicating cultural persistence from the La Tène culture into early Roman times. In order to provide answers about continuity or discontinuity in the material culture and traditions in the northern Alpine foreland from around $100 \mathrm{BC}$ to $\mathrm{AD} 100$, a multidisciplinary approach involving archaeology, zooarchaeology, anthropology, palaeobotany, and stable isotope analysis is currently being applied.

In this contribution, we focus on recent archaeological and zooarchaeological results. Following an overview of the archaeology of the area of the province of Raetia, we present the results of an ongoing analysis of the animal bone assemblages from Iron Age and Roman settlements in western and eastern Raetia and adjacent regions (Figure 1). Spatiotemporal developments in livestock composition and husbandry from the Iron Age until Roman times are addressed and evaluated with respect to (dis)continuity in animal farming practices. Since they are relevant in the context of this study, possible Mediterranean influences on livestock breeding will also be considered.

\section{Archaeology of the Celtic-Roman Transition}

The chronological starting point for this study is the Celtic 'oppida civilisation', named after the centrally located, fortified proto-urban $\mathrm{La}$ Tène settlements that Caesar called oppida (Salač, 2005: 281). Examples exist at Manching (Sievers,
2003), Kelheim (Wells, 1993), and Fentbach (Uenze, 1971). There were, however, also unfortified settlements that acted as central places, for example Berching-Pollanten (Fischer et al., 1984). Also the square ditched enclosures (Viereckschanzen; Wieland, 1999) are one of the features that characterize La Tène settlements. As part of an extensive economic network, there is evidence for a collapse of the 'oppida civilisation' around $80 \mathrm{BC}$. Postulated reasons for this include economic demise (Salač, 2005: 296), the invasion of Germanic tribes (Rieckhoff-Pauli, 1985), and human disease (Rieckhoff, 2002: 37579). Archaeologically, this decline is visible in the abandonment of central places as well as in transformations of the material culture and settlement structure.

Following the collapse of the 'oppida civilisation', small, isolated farmsteads with predominantly sunken floored buildings characterized the landscape (e.g. Irlinger, 2014). During this phase, ceramic types and traditional clothing design unequivocally reflect an influence from the Central German uplands (Mittelgebirge) and these elements are therefore considered to indicate immigration to the northern Alpine foreland (Rieckhoff, 1995: 183). Based on these findings, it has even been argued that Central Germanic tribes displaced the Celtic 'oppida civilisation' (e.g. Stöckli, 1979: 196-97). Rieckhoff-Pauli (1985: 17), however, suggests two separate waves of population movement: a first one overrunning and pillaging the northern Alpine foreland between 72 and $58 \mathrm{BC}$, followed by another migratory wave settling permanently in the largely depopulated area, where it subsequently mingled with the remaining Celtic inhabitants, thereby forming a new cultural entity. Others take the position that local Celtic people were assimilated following intense cultural contacts with the Central German uplands (Gebhard, 2004: 112). This cultural 


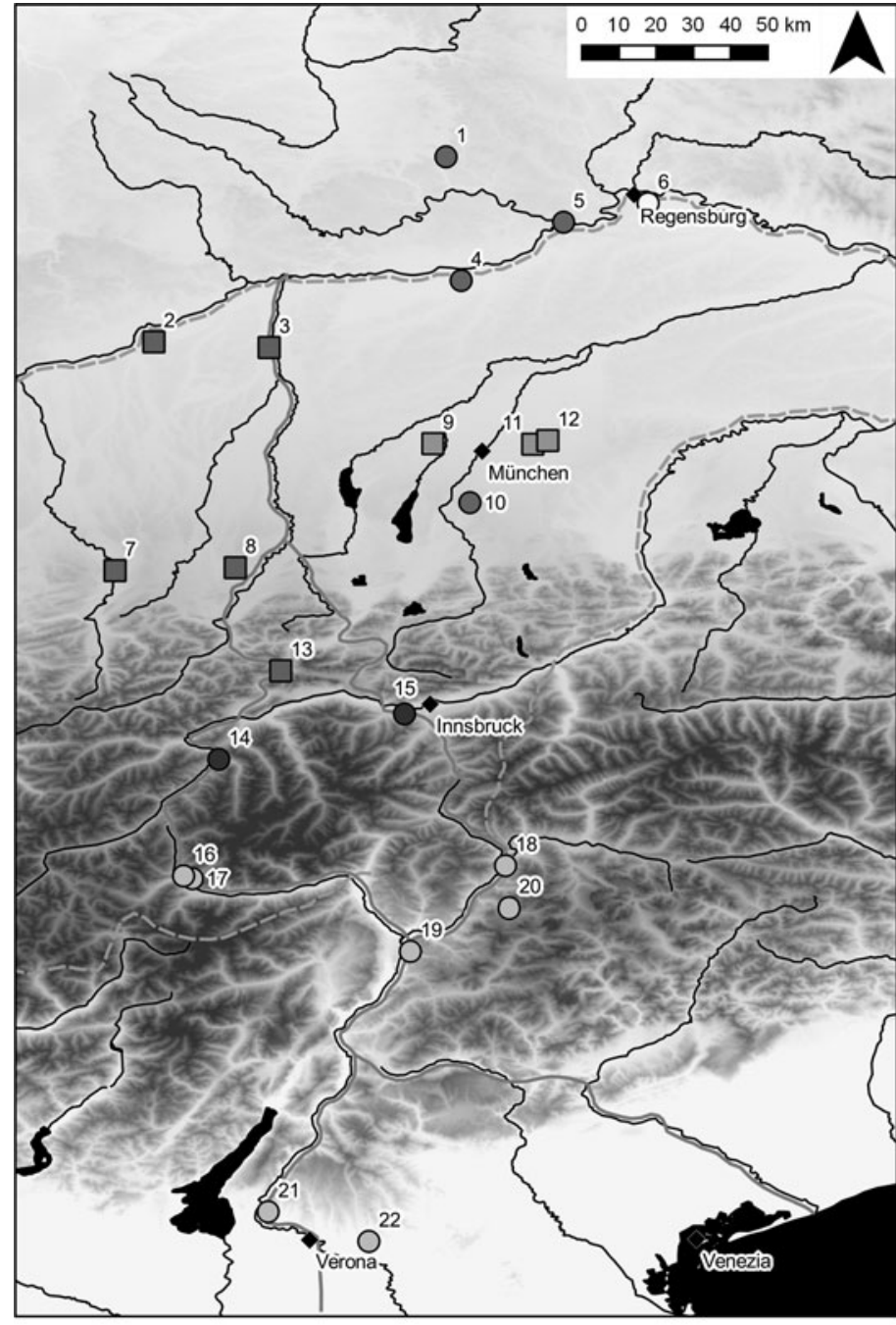

\section{Berching-Pollanten \\ 2 Aislingen}

3 Langweid

4 Manching

5 Kelheim

6 Harting

7 Kempten

8 Auerberg

9 Aubing

10 Holzhausen

11 Heimstetten

12 Poing

13 Biberwier

14 Faggen

15 Birgitz

16 Tartsch

17 Schluderns

18 Brixen

19 Leifers

20 St. Ulrich

21 San Giorgio di Valpolicella

22 Colognola ai Colli

\section{Legend}

Early Roman (Heimstetten Group)

$\square$ Early Roman (Roman-Mediterranean)

- Late Iron Age (Fritzens-Sanzeno Culture, northern group)

$\bigcirc$ Late Iron Age (Fritzens-Sanzeno Culture, southern group)

Late Iron Age (Oppida Civilisation)

$\bigcirc$ Late Iron Age (Southeast Bavarian Group)

- Via Claudia Augusta

I_- Borders of Province Raetia (1st c. AD)

- Modern Cities

Figure 1. Map of the study area with sites mentioned in the text (map basis: SRTM (Shuttle Radar Topography Mission) data; graphics: Anna-Sophie Buchhorn). 
successor to the 'oppida civilisation' is termed the Southeast Bavarian group (südostbayerische Gruppe), though both cultural milieus may have co-existed (e.g. Pietsch, 2002: 74-75).

For the Iron Age-Roman transition period, which lasted some two to three decades before and after the turn of the first century $\mathrm{BC}$ to the first century $\mathrm{AD}$, factors including (1) the paucity of sites dating to the Final La Tène period, (2) the lack of evidence for continued settlement use through to Roman times, and (3) the apparent absence of autochthonous elements in the archaeology of early Roman Imperial sites have led to the assumption that an indigenous population substrate was absent until the Roman conquest and/or had fallen into complete oblivion (e.g. Sommer, 2008: 212-15). However, results from pollen analysis (Peters, 2004: 31-38) and zooarchaeology (Peters \& Manhart, 2004: 39-52) hardly endorse such a hiatus hypothesis. Moreover, the close spatial proximity of Final La Tène and early Roman settlement remains also suggests continuity (Hüssen, 2004: 81-88). The continued use of sacrificial sites for burning animal offerings (Brandopferplätze) also point to enduring local customs. These communal places of worship have yielded finds from both Late La Tène and early Roman phases (Zanier, 1999: 108-14). But opponents of settlement continuity in the northern Alpine foreland consider these arguments to be unconvincing. Moreover, the kind and nature of the findings are often too general to identify regional differences that possibly existed and persisted in the decades marking the transition from the La Tène period to the Roman period.

Turning to the inner Alpine region, cultural developments occurred in a completely different manner. The inner Alpine Fritzens-Sanzeno culture, encompassing the historically documented Raetians
(Lang, 1998: 229), is distinct from the La Tène culture by its settlement types (e.g. Gamper, 2006), burial customs (e.g. Lang, 1998), and ritual practices (e.g. Steiner, 2010). Whereas since the second century BC Raetian groups living south of the main chain of the Alps were successively integrated into the Imperium Romanum (Demetz, 1992: 639-41), those inhabiting the main Alpine divide and its northern valleys were only assimilated much later during the military campaign of $15 \mathrm{BC}$. Thus, until the Roman conquest, Raetian settlements north of the Alpine divide were occupied continuously during the first century BC, e.g. 'Hohe Birga' in Birgitz (Tyrol, Austria) (Gleirscher, 1987: 266). Burial and worship practices as well as the material culture moreover illustrate that local traditions continued well into Roman times (Lang, 2004).

The catalyst for the military campaign of $15 \mathrm{BC}$ was the need to gain permanent control of the Alpine passes and enable the efficient transfer of people and goods between the already occupied regions of Illyria in the east and Gaul in the west. In recent years it has become possible to better document the Roman conquest and subsequent colonization thanks to new archaeological findings and historical and epigraphic data (Zanier, 2010). Clearly, development under Roman control had already begun by Augustan times. Important villages, road intersections, and thoroughfares were secured by military posts of varying sizes, e.g. at Abodiacum/ Epfach (Ulbert, 1965). Late Augustan amd especially Tiberian rule (AD 14-37) was characterized by the formation of sprawling civilian settlements including the Auerberg near Bernbeuren (Ulbert \& Zanier, 1997) and Cambodunum/ Kempten (Sieler, 2009). Their inhabitants were primarily Roman and Romanized colonists (Mackensen, 1978: 180; Ulbert \& Zanier, 1997: 124). In addition, certain 
cultural aspects point to people of Celtic (Ulbert \& Zanier, 1997: 124-25) and Germanic (Steidl, 2013: 162-69) origin. In the subsequent late Tiberian and early Claudian periods, Roman infrastructure was extended.

Archaeological evidence for Mediterranean influence is clearly visible in western Raetia and linked to the Via Claudia Augusta. This important thoroughfare connected Romanized upper Italy with the northern Alpine foreland (Figure 1).

At about the same time, eastern Raetia saw the Heimstetten group, dated to $c$. AD 30-60, flourish. Well represented in the Munich gravel plain, the Heimstetten group extends between the rivers Iller and Inn, and from the tertiary foothills to the north and the Tyrolean Inn valley to the south. The group's burial customs are probably the most characteristic sociocultural difference with the RomanMediterranean culture (e.g. Reinecke, 1957: 56). One major feature of these burials is the uniform traditional clothing for women, composed of group-specific features comprising La Tène and provincial Roman elements (Keller, 1984: 3148). Besides, the typical buildings consist of post-built structures with vertical roofbearing timbers (e.g. Volpert \& Früchtl, 2012), similar to the building forms reported from the late second/early first-century BC oppida (e.g. Steidl \& Will, 2005).

Being anomalous but coeval with early Roman provincial contexts, the Heimstetten findings provoked a lively debate about the cultural roots and geographic origin of the Heimstetten group. One hypothesis considers this cultural entity to represent the indigenous inhabitants of the Alpine foreland (e.g. Ulbert, 1959: 79). Alternatively, it has been postulated that the Heimstetten group comprises emigrants from the northern inner Alpine region (Mackensen, 1978: 49-51; Keller, 1984: 53). The most recent hypothesis, however, sees in the Heimstetten group the expression of nativism. In such a scenario the original inhabitants of an occupied area exclude their conquerors through an exaggerated accentuation of native cultural traditions (Kandil, 1983; Haffner, 1988; Zanier, 1999: 147-49).

The foregoing shows that cultural developments in the northern Alpine foreland are complex and not yet well understood in western and, particularly, eastern Raetia. However, throughout central and western Europe, the process of Romanization left a distinct imprint in the faunal record (Peters, 1998; Stopp, 2011), and this raises the question of whether zooarchaeology can throw additional light on issues like (dis)continuity in animal exploitation and hence on the cultural roots of the inhabitants of the newlyfounded province of Raetia.

\section{Zooarchaeology of the Celtic- Roman Transition}

The faunal analysis of hitherto unpublished faunal assemblages from settlement sites located in Raetia, and belonging to the Fritzens-Sanzeno culture, the Roman-Mediterranean milieu, and the Heimstetten group, forms the core of this contribution (see Figure 1 and Table 1).

The identification of the faunal remains was carried out with the aid of the comparative collection housed at the Bavarian State Collection of Anthropology and Palaeoanatomy, Munich. Data recording followed best practice as outlined in the database OssoBook (Kaltenhaler et al., 2016).

Thanks to extensive excavations at oppida sites, knowledge about Late La Tène faunal exploitation can be considered exhaustive (e.g. Boessneck et al., 1971). But for the Southeast Bavarian group the opposite is true. Given that the 
Table 1. Sites and composition (NISP) of main livestock species.

\begin{tabular}{|c|c|c|c|c|c|c|c|}
\hline \multirow[t]{2}{*}{ Archaeological culture } & \multirow[t]{2}{*}{ Site } & \multirow{2}{*}{$\begin{array}{l}\text { Number in } \\
\text { Figures } 1 \text { and } 2\end{array}$} & \multicolumn{4}{|l|}{ NISP } & \multirow[t]{2}{*}{ References } \\
\hline & & & Cattle & $\begin{array}{l}\text { Sheep/ } \\
\text { goat }\end{array}$ & Pig & $\begin{array}{l}\text { Total } \\
\text { assemblage }\end{array}$ & \\
\hline $\begin{array}{l}\text { Fritzens-Sanzeno culture } \\
\text { (north) }\end{array}$ & $\begin{array}{l}\text { Birgitz } \\
\text { Faggen }\end{array}$ & $\begin{array}{l}15 \\
14\end{array}$ & $\begin{array}{r}1062 \\
60\end{array}$ & $\begin{array}{r}1949 \\
93\end{array}$ & $\begin{array}{r}337 \\
15\end{array}$ & $\begin{array}{r}3420 \\
171\end{array}$ & $\begin{array}{l}\text { Guem, 1956; Trixl, in preparation } \\
\text { Tecchiati, } 2012\end{array}$ \\
\hline $\begin{array}{l}\text { Fritzens-Sanzeno culture } \\
\quad \text { (south) }\end{array}$ & $\begin{array}{l}\text { Brixen-Elvas* } \\
\text { Brixen-Stufels* } \\
\text { Colognola ai Colli } \\
\text { Leifers } \\
\text { San Giorgio di Valpolicella } \\
\text { Schluderns } \\
\text { St Ulrich } \\
\text { Tartsch }\end{array}$ & $\begin{array}{l}18 \\
22 \\
19 \\
21 \\
17 \\
20 \\
16\end{array}$ & $\begin{array}{r}20 \\
107 \\
698 \\
315 \\
81 \\
2482 \\
62 \\
356\end{array}$ & $\begin{array}{r}61 \\
156 \\
486 \\
233 \\
160 \\
2646 \\
74 \\
391\end{array}$ & $\begin{array}{r}8 \\
48 \\
645 \\
63 \\
257 \\
344 \\
28 \\
26\end{array}$ & $\begin{array}{r}98 \\
317 \\
2018 \\
703 \\
504 \\
5529 \\
348 \\
827\end{array}$ & $\begin{array}{l}\text { Boschin, } 2006 \\
\text { Riedel, } 1985 \\
\text { Riedel, } 1984 \\
\text { Castiglioni et al., } 2014 \\
\text { Tecchiati, 2006 } \\
\text { Schmitzberger, } 2007 \\
\text { Tecchiati \& Salvagno, } 2013 \\
\text { Schmitzberger, } 2007\end{array}$ \\
\hline Heimstetten group & $\begin{array}{l}\text { Aubing } \\
\text { Heimstetten } \\
\text { Poing }\end{array}$ & $\begin{array}{r}9 \\
11 \\
12\end{array}$ & $\begin{array}{l}306 \\
814 \\
238\end{array}$ & $\begin{array}{r}42 \\
101 \\
49\end{array}$ & $\begin{array}{r}26 \\
93 \\
111\end{array}$ & $\begin{array}{r}453 \\
1334 \\
505\end{array}$ & $\begin{array}{l}\text { Trixl, in preparation } \\
\text { Trixl, in preparation } \\
\text { Trixl, in preparation }\end{array}$ \\
\hline 'Oppida civilisation' & $\begin{array}{l}\text { Berching-Pollanten } \\
\text { Holzhausen } \\
\text { Kelheim } \\
\text { Manching } \\
\text { Munich gravel plain }\end{array}$ & $\begin{array}{r}1 \\
10 \\
5 \\
4 \\
\text { A }\end{array}$ & $\begin{array}{r}1235 \\
468 \\
492 \\
183997 \\
\\
148\end{array}$ & $\begin{array}{r}613 \\
195 \\
331 \\
88370 \\
71\end{array}$ & $\begin{array}{r}957 \\
1419 \\
562 \\
152547 \\
24\end{array}$ & $\begin{array}{r}2891 \\
2196 \\
1451 \\
452929 \\
\\
294\end{array}$ & $\begin{array}{l}\text { von den Driesch, } 1984 \\
\text { von den Driesch \& Kruszona, } 2005 \\
\text { Crabtree, } 1993 \\
\text { Boessneck et al., 1971; Hahn, 1992; Obermaier, } \\
\text { 2013; Schäffer \& Steger, } 1985 \\
\text { Schefzik, } 2001\end{array}$ \\
\hline Roman-Mediterranean & $\begin{array}{l}\text { Aislingen } \\
\text { Auerberg } \\
\text { Biberwier } \\
\text { Kempten } \\
\text { Langweid }\end{array}$ & $\begin{array}{r}2 \\
8 \\
13 \\
7 \\
3\end{array}$ & $\begin{array}{r}1375 \\
519 \\
833 \\
1961 \\
5760\end{array}$ & $\begin{array}{r}346 \\
205 \\
450 \\
1042 \\
1653\end{array}$ & $\begin{array}{r}460 \\
567 \\
1102 \\
2135 \\
3397\end{array}$ & $\begin{array}{r}2329 \\
1426 \\
2453 \\
5588 \\
11831\end{array}$ & $\begin{array}{l}\text { Trixl et al., in preparation } \\
\text { von den Driesch, } 1994 \\
\text { Trixl, in preparation } \\
\text { Trixl, in preparation } \\
\text { Trixl, in preparation }\end{array}$ \\
\hline Southeast Bavarian group & Regensburg-Harting & 6 & 126 & 84 & 104 & 370 & von den Driesch, 1995 \\
\hline
\end{tabular}


assemblages are much smaller, the animal remains provide only a preliminary insight into the kind of husbandry practised towards the end of the La Tène period and shortly before the Roman conquest. For the northern Alpine pre-Roman Fritzens-Sanzeno culture, the situation is hardly better: except for a single larger faunal sample from the 'Hohe Birga' site in Birgitz, for the third to first century BC excavations have so far only yielded smaller or less extensively published assemblages. As for the early Roman period, research into the Heimstetten group is essential but, to date, no analysis of settlement refuse associated with this cultural entity has been conducted. Finally, the early Roman-Mediterranean milieu is represented by animal remains from several settlements along the Via Claudia Augusta, with a focus on the sites of Langweid and Cambodunum/Kempten (see Figure 1 for location). ${ }^{1}$

\section{Species Composition in Iron Age Livestock Herds}

The spatio-temporal comparison of the Iron Age faunal assemblages studied clearly illustrates regional differences in livestock composition and consequently in farming practices (Figure 2). One major reason for this is that throughout the study area, eco-geographic conditions varied considerably, whilst the presence of human groups of different cultural origin since the Late Iron Age is also likely to have played a role. Locational details as well as socio-cultural aspects must therefore be factored in when interpreting livestock species composition and breeding targets.

1 The still unpublished animal bone assemblages (see also Table 1) will be published in a monograph including all primary data, which is expected to appear in 2018.
As would be expected, faunal assemblages from Late Iron Age sites situated in mountainous regions are characterized by high proportions of small ruminants (Riedel, 1986: 60; Peters, 1998: 381, fig. 14). This predominance of sheep and goat relates to their more efficient use of the often sparse and dispersed vegetation cover in landscapes with steep, rugged mountain sides. Significantly, higher proportions of small ruminants are reported from Bronze and Iron Age settlements in Trentino and South Tyrol, which possess little fertile land suitable for agriculture (Riedel \& Tecchiati, 1999: 109). In order to protect the agricultural plots at lower altitudes that were essential for the supply of fodder and winter grazing (e.g. Putzer, 2013: 27) and of staples for human consumption, the inhabitants of the inner Alpine region exploited pastures at higher altitudes since prehistoric times. Demonstrating seasonal vertical transhumance is, however, fraught with problems (Reitmaier, 2010). Be that as it may, exploitation of high pastures may have started as early as the Neolithic (Deschler-Erb et al., 2015: 373), growing in intensity during and particularly after the Bronze Age (Carrer, 2013: 49-51). The keeping of livestock at high altitudes is usually linked to milk and cheese production, which one might have expected to come from cattle; it is nonetheless clear that in steeper and more sparsely vegetated rocky habitats above the timberline herders preferred small livestock over cattle.

For the period considered here, vertical transhumance is suggested by La Tène building structures likely to represent shepherds' huts, e.g. at Schwarzboden in the Maneid valley/Vinschgau (Putzer, 2009: 35-36) and at Pitschedboden near Ainet/East Tyrol (Staudt et al., 2014). Moreover, the examination of the La Tène fauna from the rock shelter of Hexenfelsen in the Rofan Mountains (Northern Limestone Alps; c. $2000 \mathrm{~m}$ asl) 


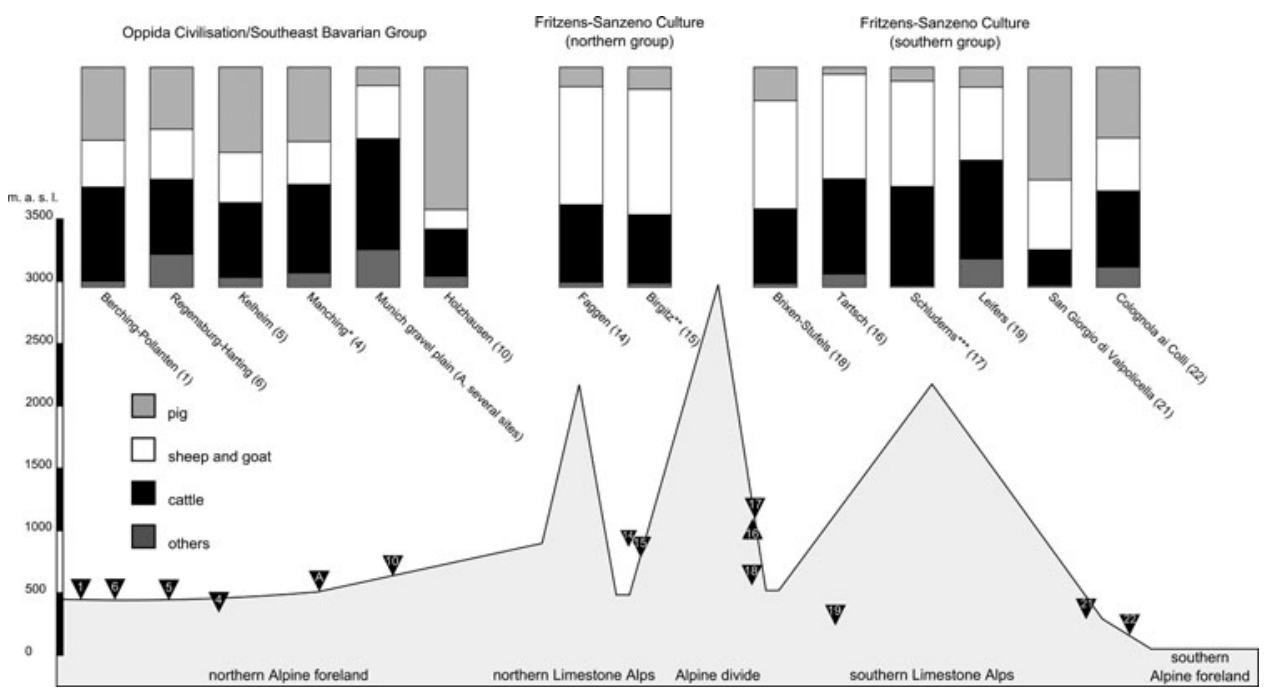

Figure 2. Proportion of main livestock species in the foreland and inner Alpine sites during the La Tène period by specimen counts. Based on own research and published data (see Table 1). *Data from complete excavations between 1955 and 1999; data from past and new excavations; * data from complete material of the Middle and Late La Tène period.

has revealed that 95.5 per cent of the animal bones belong to small ruminants (Bachnetzer \& Nutz, 2010: 35), underscoring their economic importance in this subalpine ecosystem.

In the Late Iron Age assemblages considered here, the proportion of cattle differs considerably between sites located in the inner Alpine region and the northern and southern foreland (Figure 2). In view of the cattle's live weight and lifetime products including milk, dung and labour, however, cattle played a key role in almost all Alpine economies, even if numerically the species ranks second behind small livestock.

La Tène faunal assemblages from sites located in the northern Alpine foreland are characterized by comparably high proportions of pigs. The species is also quite prominent in the southern Alpine piedmont, where the mountain valleys open towards the Po plain, the catchment basin of the river Po. In the inner Alpine setting, however, pig husbandry played a less important role, as would be expected (e.g. Peters, 1998; Riedel \& Tecchiati, 1999), except for the site of San Giorgio di Valpolicella. Here the relatively high number of pig bones is probably owed to ritual activities for which there is archaeological evidence (Tecchiati, 2006). According to Schmitzberger (2007: 68081 , the absence of beech and oak in an east-west stretch south of the main Alpine divide is likely to have inhibited the raising of pigs in any great numbers in the southern inner Alpine landscape. North of the Alpine divide, in the valley of the river Inn, however, beech trees still grow today at higher elevation in the mountains and sometimes even predominate there. Pollen analyses illustrate that in prehistoric times deciduous woodland was even more extensive in the Inn valley and that it shrank during the Neolithic period and in the metal ages in particular (Oeggl, 2013). Suitable forest habitat providing these highly nutritive dietary staples must nonetheless have been available north of the main Alpine divide considering the occasional presence of sites with decidedly 
higher quantities of pig, for instance at Late Roman Teriola/Zirl (Pucher, 2003). It must therefore be questioned whether the minor contribution of pigs in La Tène settlements in the Tyrolean Inn valley relates exclusively to the lack of suitable forest habitat or if there is a cultural reason for this.

Interestingly, once dairy production and cheese making became major activities in Alpine subsistence, pigs (re-)gained in economic importance: whey, a major byproduct when making cheese, is particularly well suited as a dietary supplement for fattening pigs. This explains why, until the nineteenth century $\mathrm{AD}$, pigs were driven in significant numbers to Alpine pastures (Werner, 1981: 36).

\section{Osteometric Comparison of Iron Age Livestock Species}

In light of the differences in subsistence strategies throughout the study area, we should ask whether the animals kept by the people of the Fritzens-Sanzeno culture in the inner Alpine region differed phenotypically from their relatives in the Alpine foreland. One standard method to approach this question is comparative osteometry, but sample size may be an issue. For the Late La Tène northern Alpine foreland, for instance, there are sufficient measurement data because oppida assemblages have been well studied (e.g. Boessneck et al., 1971). With respect to the inner Alpine FritzensSanzeno culture, however, only sparse metrical data are available for Late Iron Age cattle and even less exist for pigs. It has therefore been necessary to combine measurements from different skeletal elements. This was done by applying the logarithmic size index method (LSI; Meadow, 1999; Wickham, 2009; analyses based on R and ggplot 2: R Core Team, 2014). Despite this, the small sample size for pigs across the study area still prohibited size comparison for this species.

With respect to the sheep raised in the northern Alpine foreland and the northern and southern inner Alpine regions respectively, no statistically significant differences in size could be found (Figure 3a). Moreover, the range and distribution of the values in the box-and-whisker plots strongly suggests that we are dealing with fairly homogenous populations.

As for cattle, the populations kept by the inhabitants of the oppida of the northern Alpine foreland (Manching, Berching-Pollanten) appear on average slightly more robustly built compared to their relatives in the contemporaneous inner Alpine region (Figure 3b). Statistical comparison (Kruskal-Wallis test with Bonferroni correction (Field et al., 2012)) shows, however, that most differences are not significant; additional finds from the inner Alpine region are necessary to clarify this issue. The somewhat smaller body mass of Alpine cattle, as suggested by the osteometric comparison, can probably be explained by poor husbandry conditions and environmental stress, caused by long winters and fluctuating availability of food so typical of mountainous regions. However, prior to the introduction of modern technologies, smaller-sized cattle breeds, well-adapted to the harsh conditions of the Alps, benefitted from a long tradition that can be traced back to the Bronze and Iron Ages (Pucher, 2006, 2010). By contrast, clearly larger-sized cattle were present in the southern Alpine foreland in the period, e.g. in the Veneto (Riedel, 1986: 18-19).

\section{Animal Husbandry in the Early Roman Northern Alpine Foreland}

Cultural changes caused by the incorporation of a new region into the Imperium 

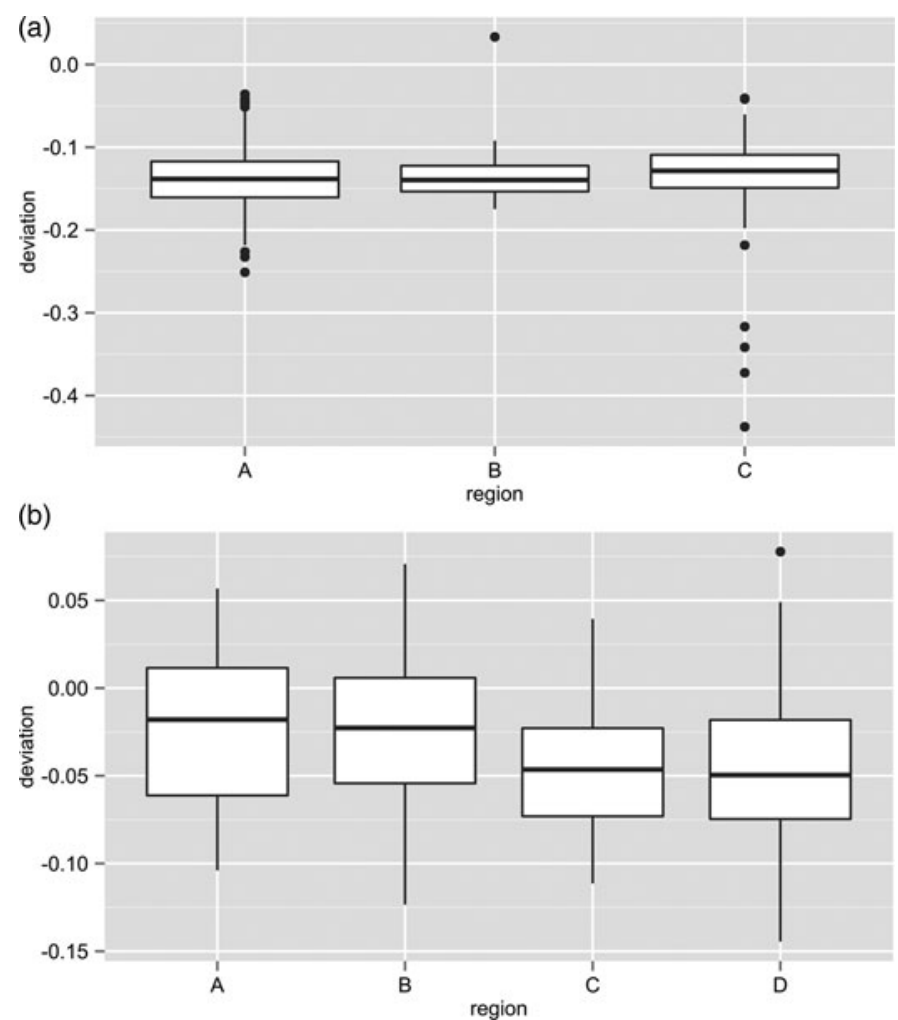

Figure 3. Size comparison of La Tène-period sheep and cattle using LSI (logarithmic size index). Based on own research and published data (see Table 1). 3(a): LSI for sheep. A: 'oppida civilisation' $(n=13,782), B$ : Fritzens-Sanzeno culture, northern group $(n=34), C$ : Fritzens-Sanzeno culture, southern group $(n=153)$. 3(b): LSI for cattle: A: Berching-Pollanten ('oppida civilisation'; $n=33$ ), B: Manching ('oppida civilisation'; $n=171), C$ : Fritzens-Sanzeno culture, northern group $(n=16)$, D: Fritzens-Sanzeno culture, southern group $(n=97)$.

Romanum were accompanied not only by societal and economic transformation, but also by marked changes in animal husbandry and breeding targets, as evidenced for instance in Gaul (e.g. Méniel, 1993; Lepetz, 2008), the Iberian Peninsula (Colominas, 2013), and the Roman northwestern provinces of Germania, Raetia, and Noricum (Peters, 1998). In inner Alpine Raetia, and for reasons of ecogeography, however, the Roman animal economy continued to have high proportions of small ruminants (Riedel \& Rizzi, 1994: 236; Donat et al., 2006). The combination of archaeozoological data with the archaeological evidence (e.g. Segard,
2009) and the pollen record (e.g. Oeggl, 1994) documenting the exploitation of mountain pastures in Antiquity indicates that, in Alpine economies, caprine herding continued to be a cornerstone of animal subsistence.

Compared to the inner Alpine region, more detail is available for the Early Imperial northern Alpine foreland. As mentioned before, there are two different scenarios with respect to the presence of indigenous groups in the northern Alpine foreland at the onset of the Roman conquest. Once under Roman control, cultural (including faunal) developments would have been broadly similar across the 
northern Alpine foreland, according to current opinion. But ongoing faunal analysis of Early Imperial sites in the northern Alpine foreland does not confirm this picture. With respect to animal farming, the Heimstetten group in north-eastern Raetia stands out in many ways. As illustrated in Figure 4, the faunal assemblage of the eponymous site of Heimstetten contains large proportions of cattle and equids. Conversely, caprines and pigs-i.e. farmyard species that were well represented in the preceding settlements of the La Tène 'oppida civilisation' and the Southeast Bavarian group as well as in early Romanized contexts along the Via Claudia Augusta in north-western Raetia-only make a minor contribution (Figure 4a, see also Figure 2). Faunal assemblages from other Heimstetten group sites (Aubing, Poing) support this assessment (Figure 4b). Since the Heimstetten group bone assemblages from the Munich gravel plain are poorly preserved, the question arises of whether taphonomic bias favoured the survival of remains of large mammals at sites located there. This seems not to be the case because, from prehistory (Schefzik, 2001: 171-76) up to early medieval times (Schäffer \& von den Driesch, 1983: 33, tab. 1), cattle always ranked first, whilst small ruminants and pigs fluctuated in numbers. This is also true for the early medieval settlement of Kirchheim, which is located in the immediate vicinity of the eponymous site of Heimstetten (Schäffer \& von den Driesch, 1983: 33, tab. 1). Another feature typical for the Munich gravel plain is that most animal remains associated with the Heimstetten group come from archaeological contexts like pits and well shafts. The latter also contained partial skeletons, but, since we focus on meat supply, these were excluded from our calculations.

Telling changes are also reflected in the overall size of cattle, as shown by the logarithmic size index calculated for populations excavated in La Tène-period and Roman-Mediterranean influenced settlements compared to the site of Heimstetten (Figure 5). With respect to the cattle raised in the vicinity of the newly-founded Roman settlements along or near the Via Claudia Augusta at Aislingen, Auerberg, Cambodunum/ Kempten, and Langweid, only a minor increase in body size could be observed compared to cattle from the preceding $\mathrm{La}$ Tène period. Moreover, the distribution of the values in the plots of these early Roman populations points to an amalgam of different types of cattle. Conceivably, in order to achieve their breeding targets, early Roman cattle breeders selected indigenous stock for crossing with imported larger-sized (male) individuals exhibiting the desired characteristics and phenotype. In this way a gradual improvement in the performance of landrace breeds that were optimally adapted to the local landscape and vegetation would be achieved. The continuous size development on the one hand, and the appearance of some large individuals as well as a limited, initial increase in bone size on the other, points to such a practice during the first century AD. Presumably the need for strong animals to pull heavy loads or cultivate extensive fields was at the origin of this development, but an increasing demand for meat seems to be an option as well. In all Roman-Mediterranean settlements, females strongly dominate the adult age cohort, which points to selective slaughter of immature males. Nonetheless, it seems that local breeds persisted. The reason for this may have been the lower milk production in hybrid cows-according to the Roman writers on agriculture, Mediterranean breeds were not very prolific in this respect-combined with continued demand for dairy milk by the local human population (Peters \& Manhart, 2004). 

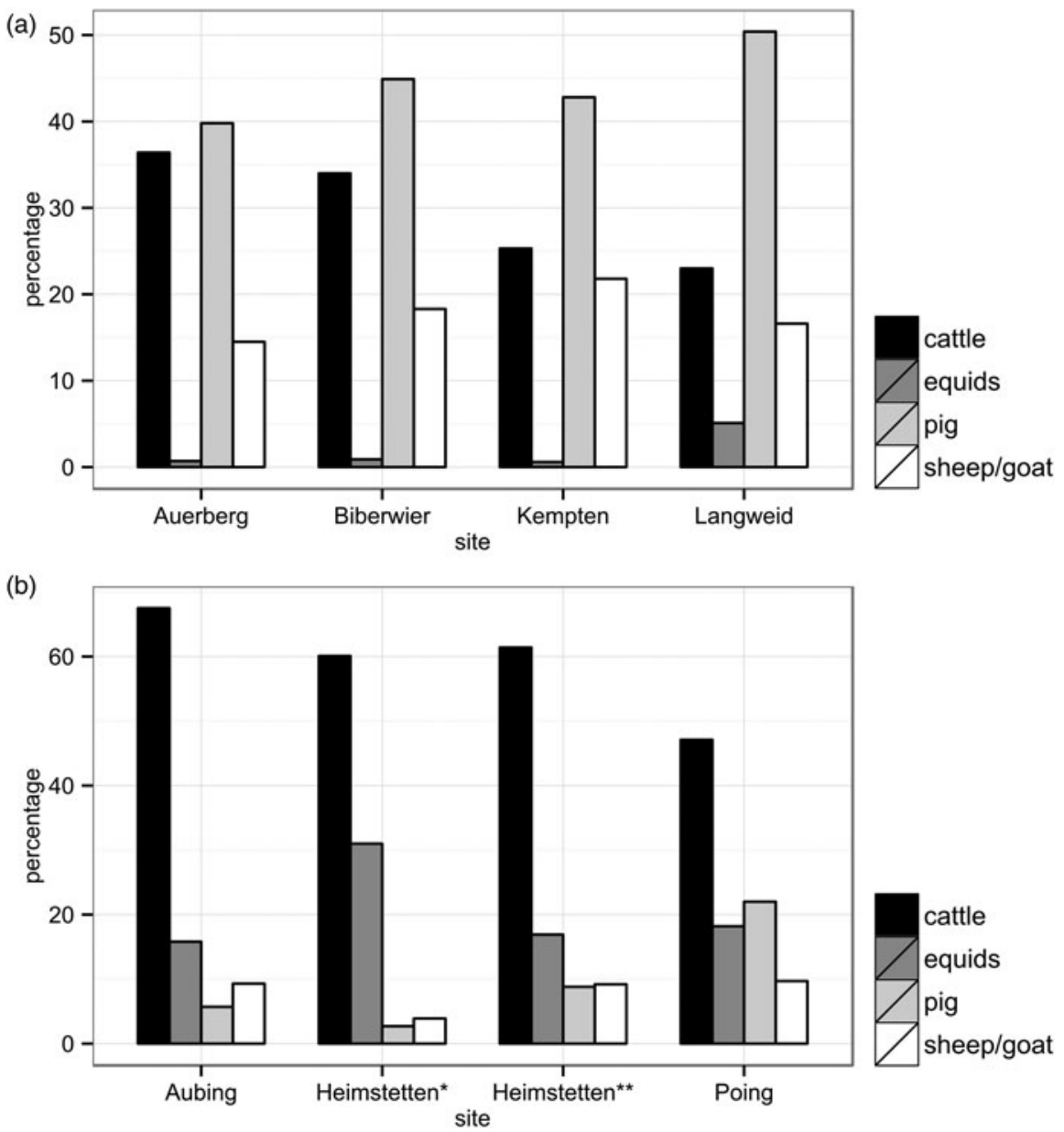

Figure 4. Relative proportions of main livestock species in Roman Raetia based on NISP counts. 4(a): Roman-Mediterranean sites: Auerberg , Biberwier (c. first century AD), Cambodunum/Kempten (only late Augustan to early Claudian occupation period; $n=1044$ ) and Langweid (only late Augustan/early Tiberian to Claudian occupation period; $n=713)$. 4(b): Heimstetten group sites: Aubing (complete assemblage), Heimstetten ("first century $A D ; n=406$; *late first to early second century $A D ; n=928$ ) and Poing (complete assemblage).

The metric data obtained from the Heimstetten group show a completely different picture. By the middle of the first century $\mathrm{AD}$, body size in cattle had already surpassed that of their La Tène-period relatives by a wide margin. The narrow distribution of their values (Figure 5) indicates a rather uniform population that does not fit the model of slow amelioration across many generations including local breeds. One possible explanation is that we are dealing with an imported breed, whose region of birth still needs to be identified through stable isotope analysis. Alternatively, systematic replacement of local stock by out-breeding must be considered. In this case, performance is enhanced rapidly by back-crossing with parental stock. In doing so, the genetic make-up is halved with each subsequent generation, and after only six generations, or about fifteen years, a mere 1.6 per cent 


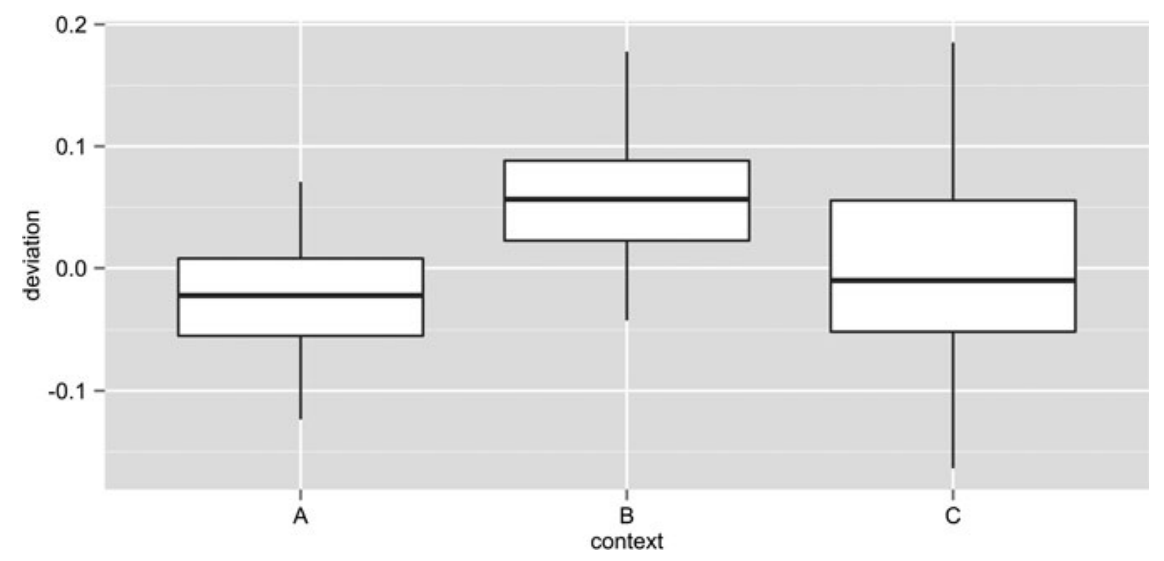

Figure 5. LSI (logarithmic size index) of: A: 'oppida civilisation' cattle populations ( $n=217)$ ); $B$ : the Heimstetten group $(n=28)$; and $C$ : the Roman-Mediterranean milieu $(n=434)$. Based on own research and published data (see Table 1).

of the local breed's original genetic makeup remains (Sambraus, 1994: 23). Unfortunately, the ratio males to females in the assemblage cannot be specified due to small sample size and high degree of fragmentation.

This raises the question why such amelioration is not evidenced in early Roman urban centres like Cambodunum/ Kempten. Possibly the meat supply of the newly-founded settlements at the foot of the Alps was based on indigenous Celtic/ Raetic montane-adapted breeds reported to be of small stature (e.g. Pliny, Natural History, VIII.70). Pollen analysis within the site catchments of the early Roman sites of Auerberg (Küster, 1986) and Biberwier (Oeggl, 1998) support the hypothesis of continuity in Late La Tène/ early Roman land use. Presumably these well-established traditional methods of food production sufficed to cover the needs of the early colonists. This diet was supplemented with the meat of pigs and chicken, two species typical for Roman urban centres and likely to have been bred locally.

Besides species composition and size in cattle, several other characteristics in the animal bone assemblages of the
Heimstetten group distinguish this cultural entity from Romanized sites along the contemporaneous Via Claudia Augusta. Examples include the low visibility of poultry farming (if at all) and the way carcasses were treated during butchery (implying Iron Age roots), but these aspects will be treated elsewhere. The investigation of slaughter ages, to examine differences in animal exploitation strategies, would be of interest too. But comparison of age profiles in livestock from Roman-Mediterranean and first century AD Heimstetten group sites is hampered by the very low frequency of dental remains in the latter, precluding any test or statistical analysis.

\section{Concluding Remarks}

From the foregoing we can conclude that faunal developments in the Munich gravel plain are distinct from those observed on contemporary settlements in western Raetia, which was clearly more susceptible to Roman influence. Whereas sites in the catchment area of the Via Claudia Augusta bear testimony to the Roman-Mediterranean lifestyle in their architecture, material 
culture, and patterns of animal exploitation, such as specialized meat processing-i.e. smoking of meat, characteristic carcass processing - and the appearance of imported animals (probably 'lapdogs' and certainly sea shells), people living in the Munich gravel plain in the first century $\mathrm{AD}$ seem to have been quite reluctant towards external cultural influences. Most interestingly, the La Tène-influenced, nativist Heimstetten group struck new ground in the breeding of cattle. In a region poor in geographical assets and natural resources, husbandry of large livestock may have offered a sustainable income for the inhabitants of the Munich gravel plain since the Early Bronze Age (Schefzik, 2001: 175). Clearly, the exploitation of this landscape did not change in the Roman period. Presumably cattle breeding filled an economic niche that could perhaps offer an explanation for the extraordinary outfit of the female deceased. The fact that cattle breeding was one of the economic mainstays in the Munich gravel plain since prehistory is a major argument against the hypothesis that people of the Heimstetten group immigrated from the Inn valley. As shown above, livestock breeding in the FritzensSanzeno culture focused on sheep, and it is reasonable to assume that on the Munich gravel plain sheep husbandry would have been successful if people had chosen to pursue it.

To conclude, fundamental differences in animal husbandry practices between the Fritzens-Sanzeno culture and the Heimstetten group make an inner Alpine origin of the latter unlikely. Rather, continuity in building tradition, burial customs, and large livestock farming all point to a cultural entity rooted in the tradition of the preceding $\mathrm{La}$ Tène culture. Future study of bioarchaeological assemblages covering the period of transition between the Iron Age and the
Roman period, as well as the application of stable isotope analysis and palaeogenetics to human and animal remains, will help ascertain whether this hypothesis holds or whether further explanatory models are required.

\section{AcKNowledgements}

The funding of the project 'Transalpine mobility and cultural transfer' by the German Research Council (Deutsche Forschungsgemeinschaft, DFG, PE 424/11-1, 2) is gratefully acknowledged. G. McGlynn kindly provided a translation of this contribution.

\section{REFERENCES}

Bachnetzer, T. \& Nutz, B. 2010. Der Hexenfels am Krahnsattel im Rofangebirge, Nordtirol. Archäologie Österreichs, 21: 35-38.

Boessneck, J., von den Driesch, A. \& Wechsler-von Ohlen, E. 1971. Die Tierknochenfunde aus dem Oppidum von Manching. Wiesbaden: Steiner.

Boschin, F. 2006. La fauna protostorica del sito di Bressanone-Elvas (BZ). In: U. Tecchiati \& I. Sala, eds. Archaeozoological Studies in Honour of Alfredo Riedel. Bolzano: Ufficio Beni Archeologici, pp. 131-42.

Carrer, F. 2013. Archeologia della pastorizia nelle Alpi: nuovi dati e vecchi dubbi. Preistoria Alpina, 47: 49-56.

Castiglioni, E., Dal Ri, L., Leitner, B., Tecchiati, U., Cottini, M. \& Groppi, F. 2014. Laives Reif: approccio multidisciplinare allo studio di un abitato della seconda età del Ferro in Val d'Adige. In: R. Roncador \& F. Nicolis, eds. Antichi popoli delle Alpi. Sviluppi culturali durante l'età del Ferro nei territori alpini centro-orientali. Trento: Provincia autonoma di Trento, pp. 105-25.

Colominas, L. 2013. Arqueozoología y Romanización. Producción, distribución y consumo de animales en el nordeste de la Peninsula Ibérica entre los siglos $V$ ane- $V$ dne. Oxford: Archaeopress. 
Crabtree, P. 1993. Vertebrate Faunal Remains from Kelheim. In: P. Wells, ed. Settlement, Economy and Cultural Change at the End of the European Iron Age: Excavations at Kelheim, Bavaria, 19871991. Ann Arbor (MI): International Monographs in Prehistory, pp. 61-65.

Demetz, S. 1992. Rom und die Räter. Ein Resümee aus archäologischer Sicht. In: I. R. Metzger \& P. Gleirscher, eds. Die Räter. Bozen: Athesia, pp. 631-53.

Deschler-Erb, S., Ginella, F. \& HüsterPlogmann, H. 2015. Archäozoologische Untersuchungen $\mathrm{zu}$ den prähistorischen und mittelalterlichen Funden vom Kiechlberg. In: U. Töchterle, ed. Der Kiechlberg bei Thaur als Drebscheibe zwischen den Kulturen nördlich und südlich des Alpenhauptkammes. Ein Beitrag zum Spätneolitbikum und zur Früb- und Mittelbronzezeit in Nordtirol. Bonn: Habelt, pp. 361-96.

Donat, P., Flügel, C. \& Petrucci, G. 2006. Fleischkonserven als Produkte römischer Almwirtschaft. Schwarze Auerbergkeramik vom Monte Sorantri bei Raveo (Friaulisch-Julisch-Venetien, Nordostitalien). Bayerische Vorgeschichtsblätter, 71: 209-32.

Field, A., Miles, J. \& Field, Z. 2012. Discovering Statistics Using $R$. Los Angeles, London, New Delhi, Singapore, Washington DC: SAGE Publications.

Fischer, T., Rieckhoff-Pauli, S. \& Spindler, K. 1984. Grabungen in der spätkeltischen Siedlung im Sulztal bei Berching-Pollanten, Landkreis Neumarkt, Oberpfalz. Germania, 62: 311-72.

Gamper, P. 2006. Die latènezeitliche Besiedlung am Ganglegg in Südtirol. Neue Forschungen zur Fritzens-Sanzeno-Kultur. Rahden: Marie Leidorf.

Gebhard, R. 2004. Die spätkeltische Gräbergruppe von Hörgertshausen, Lkr. Freising. In: C.-M. Hüssen, W. Irlinger \& W. Zanier, eds. Spätlatènezeit und frühe römische Kaiserzeit zwischen Alpenrand und Donau. Akten des Kolloquiums in Ingolstadt 11.-12. Oktober 2001. Bonn: Habelt, pp. 105-12.

Gleirscher, P. 1987. Die Kleinfunde von der Hohen Birga bei Birgitz. Ein Beitrag zur Fritzens-Sanzeno-Kultur. Berichte der RömischGermanischen Kommission, 68: 181-351.

Guem, F. 1956. Vorgeschichtliche Tierreste aus Tirol. Eine naturwissenschaftlichkulturhistorische Untersuchung an späträtischen Knochenfunden aus Birgitz, Ranggen und Himmelreich in Volders (unpublished $\mathrm{PhD}$ dissertation, University of Innsbruck).

Haffner, A. 1988. Review of Keller, E. Die frühkaiserzeitlichen Körpergräber von Heimstetten 1984. Germania, 66: 233-34.

Hahn, E. 1992. Die Tierknochenfunde. In: F. Maier, U. Geilenbrügge, E. Hahn, H.-J. Köhler \& S. Sievers, eds. Ergebnisse der Ausgrabungen 1984-1987 in Manching. Stuttgart: Steiner, pp. 235-69.

Hüssen, C.-M. 2004. Besiedlungswandel und Kontinuität im oberbayerischen Donauraum und in der Münchner Schotterebene von der Okkupation unter Augustus bis in tiberisch-claudische Zeit. In: C.-M Hüssen, W. Irlinger \& W. Zanier, eds. Spätlatènezeit und frühe römische Kaiserzeit zwischen Alpenrand und Donau. Akten des Kolloquiums in Ingolstadt 11.-12. Oktober 2001. Bonn: Habelt, pp. 73-91.

Irlinger, W. 2014. Ein endlatènezeitlicher Siedlungsbefund aus Schambach, Gemeinde Straßkirchen, Landkreis Straubing-Bogen. In: L. Husty, W. Irlinger \& J. Pechtl, eds. "...und es hat doch was gebracht!" Festschrift für Karl Schmotz zum 65. Geburtstag. Rahden: Marie Leidorf, pp. 315-30.

Kaltenthaler, D., Lohrer, J., Kröger, P., van der Meijden, C., Granado, E., Lamprecht, J., Nücke, F., Obermaier, H., Stopp, B., Baly, I., Callou, C., Gourichon, L., Pöllath, N., Peters, J. \& Schibler, J. 2016. OssoBook v5.3.3. München \& Basel [online] [accessed 17 August 2016]. Available at: http://xbook. vetmed.uni-muenchen.de/wiki/OssoBook.

Kandil, F. 1983. Nativismus in der Dritten Welt. Wiederentdeckung der Tradition als Modell für die Gegenwart. Sankt Michael: Bläschke.

Keller, W. 1984. Die frübkaiserzeitlichen Körpergräber von Heimstetten bei München und die verwandten Funde aus Südbayern. München: Beck.

Küster, H. 1986. Werden und Wandel der Kulturlandschaft im Alpenvorland. Pollenanalytische Aussagen zur Siedlungsgeschichte am Auerberg in Südbayern. Germania, 64: 533-59.

Lang, A. 1998. Das Gräberfeld von Kundl im Tiroler Inntal. Studien zur vorrömischen Eisenzeit in den zentralen Alpen. Rahden: Marie Leidorf. 
Lang, A. 2004. Der Übergang von der späten Latènezeit zur frühen römischen Kaiserzeit in Nordtirol. In: C.-M Hüssen, W. Irlinger \& W. Zanier, eds. Spätlatènezeit und frühe römische Kaiserzeit zwischen Alpenrand und Donau. Akten des Kolloquiums in Ingolstadt 11.-12. Oktober 2001. Bonn: Habelt, pp. 199-209.

Lepetz, S. 2008. L'amélioration des espèces animales domestiques à la période romaine en France du Nord. In: D. Meeks \& D. Garcia, eds. Techniques et économie antiques et médiévales: le temps d'innovation. Colloque international (CNRS.) Aix-enProvence 1996. Paris: Errance, pp. 157-65.

Mackensen, M. 1978. Das römische Gräberfeld auf der Keckwiese in Kempten I. Gräber und Grabanlagen des 1. und 4. Jahrhunderts. Kallmünz: Lassleben.

Meadow, R. 1999. The Use of Size Index Scaling Techniques for Research on Archaeozoological Collections from the Middle East. In: C. Becker, H. Manhart, J. Peters \& J. Schibler, eds. Historia animalium ex ossibus. Beiträge zur Paläoanatomie, Archäologie, Ägyptologie, Ethnologie und Geschichte der Tiermedizin. Festschrift für Angela von den Driesch zum 65. Geburtstag. Rahden: Marie Leidorf, pp. 285-300.

Meixner, E. \& Pütz, A. 2013. Bürstenstrich und Fingerkniff - Endlatènezeitliche Siedlung mit vielversprechender Keramik von Aschheim. Das archäologische Jahr in Bayern, 33: 66-69.

Méniel, P. 1993. Les restes animaux de l'oppidum du Titelberg (Luxembourg) de La Tène finale au Gallo-Romain précoce. Archaeologia Mosellana, 2: 381-406.

Obermaier, H. 2013. Tierknochen aus Manching-Altenfeld - eine Auswahl aus verschiedenen Arealen. In: S. Sievers, M. Leicht \& B. Ziegaus, eds. Ergebnisse der Ausgrabungen in Manching-Altenfeld 1996-1999. Wiesbaden: Reichert, pp. 709-36.

Oeggl, K. 1994. The Palynological Record of Human Impact on Highland Zone Ecosystems. In: P. Biagi \& J. Nandris, eds. Highland Exploitation in Southern Europe: International Round Table 'Highland Zone Exploitation in Southern Europe', Brescia, 29 April-1 May 1993 (Natura Bresciana 20). Brescia: Museo Civico di Scienze Naturali, pp. 107-22.
Oeggl, K. 1998. Palynologische Untersuchungen aus dem Bereich des römischen Bohlenweges bei Leermoos, Tirol. In: E. Walde, ed. Via Claudia. Neue Forschungen. Telfs: Hörtenbergdruck, pp. 147-71.

Oeggl, K. 2013. Die Vegetations- und Siedlungsgeschichte im mittleren Unterinntal seit dem Neolithikum. In: K. Oeggl \& V. Schaffer, eds. Cuprum Tyrolense. 5550 Jabre Bergbau und Kupferverbüttung in Tirol. Brixlegg: Edition Tirol, pp. 29-54.

Peters, J. 1998. Römische Tierhaltung und Tierzucht. Eine Synthese aus archäozoologischer Untersuchung und schriftlich-bildlicher Überlieferung. Rahden: Marie Leidorf.

Peters, J. \& Manhart, H. 2004. „... und jegliches heimische Rind ist weit besser als ein auswärtiges..." Zur Frage der Kontinuität keltischer Viehwirtschaft im süddeutschen Raum. In: C.-M Hüssen, W. Irlinger \& W. Zanier, eds. Spätlatènezeit und frühe römische Kaiserzeit zwischen Alpenrand und Donau. Akten des Kolloquiums in Ingolstadt 11.-12. Oktober 2001. Bonn: Habelt, pp. 39-52.

Peters, M. 2004. Landschaftsentwicklung in Südbayern von der Eisenzeit bis zur Völkerwanderungszeit - Kontinuität oder Diskontinuität? Ergebnisse der Pollenanalytik. In: C.-M Hüssen, W. Irlinger \& W. Zanier, eds. Spätlatènezeit und frühe römische Kaiserzeit zwischen Alpenrand und Donau. Akten des Kolloquiums in Ingolstadt 11.-12. Oktober 2001. Bonn: Habelt, pp. 31-38.

Pietsch, M. 2002. Eine neue spätkeltische Höhensiedlung bei Marktl a. Inn. Das Archäologische Jahr in Bayern, 22: 72-75.

Pliny the Elder 2007. Gaius Plinius Secundus Maior, Naturalis historia, trans. by L. Möller \& M Vogel. Wiesbaden: Marix Verlag.

Pucher, E. 2003. Ein kleiner Tierknochenfundkomplex aus dem spätrömischen Kastell Teriola auf dem Maienbühel bei Zirl in Tirol. In: A. Höck, ed. Die Rettungsgrabungen auf dem Martinsbühel bei Zirl von 1993 bis 1997. Spätrömische Befunde und Funde zum Kastell. Horn: Berger, pp. 91-100.

Pucher, E. 2006. Steirische Bergschecken und die vergessene Frage nach der Geschichte der Rinderrassen. In: F. Mandl, ed. Alpen. Archäologie, Geschichte, Gletscherforschung, 
Festschrift 25 Jahre ANISA. Haus im Ennstal: Verein ANISA (Verein für alpine Forschung), pp. 263-92.

Pucher, E. 2010. Sechs Jahrtausende alpine Viehwirtschaft. ANISA, 12: 1-28.

Putzer, A. 2009. Eine prähistorische Almhütte auf dem Schwarzboden im Maneidtal, Südtirol/Vinschgau. Archaeologia Austriaca, 93: 33-43.

Putzer, A. 2013. Königinnen der Almen. Prähistorische Weidewirtschaft im Schnalstal. Der Schlern, 87: 4-31.

R Core Team, 2014. R: A Language and Environment for Statistical Computing. Vienna: R Foundation for Statistical Computing, (http://www.R-project.org/).

Reinecke, P. 1957. Skelettgräber der frühen Kaiserzeit in Raetien. Bayerische Vorgeschichtsblätter, 22: 36-59.

Reitmaier, T. 2010. Auf der Hut - Methodische Überlegungen zur prähistorischen Alpwirtschaft in der Schweiz. In: F. Mandl \& H. Stadler, eds. Archäologie der Alpen. Haus im Ennstal: Verein ANISA (Verein für alpine Forschung), pp. 219-38.

Rieckhoff, S. 1995. Süddeutschland im Spannungsfeld von Kelten, Germanen und Römern. Studien zur Chronologie der Spätlatènezeit im südlichen Mitteleuropa. Trier: Rheinisches Landesmuseum Trier.

Rieckhoff, S. 2002. Der Untergang der Städte. Der Zusammenbruch des keltischen Wirtschafts- und Gesellschaftssystems. In: C. Dobiat, S. Sievers \& T. Stöllner, eds. Dürnberg und Manching. Wirtschaftsarchäologie im ostkeltischen Raum. Akten des internationalen Kolloquiums in Hallein Bad Dürrnberg vom 7. bis 11. Oktober 1998. Bonn: Habelt, pp. 359-79.

Rieckhoff-Pauli, S. 1985. Kelten, Germanen und Römer im 1. vorchristlichen Jahrhundert. In: Bayerisches Landesamt für Denkmalpflege, ed. Die Römer in Schrwaben. München: Bayerisches Landesamt für Denkmalpflege, pp. 15-17.

Riedel, A. 1984. The Fauna of the Excavations of Colognola ai Colli Verona, Northern Italy, Iron Age. Bollettino del Museo Civico di Storia Naturale di Verona, 11: 277-318.

Riedel, A. 1985. Ergebnisse der Untersuchung einiger Südtiroler Faunen. Preistoria Alpina, 22: 113-77.

Riedel, A. 1986. Archäozoologische Untersuchungen im Raum zwischen Adriaküste und Alpenhauptkamm. Padusa, 22: 1-220.
Riedel, A. \& Rizzi, J. 1994. Resti faunistici domestici e selvatici: produzione e consumo. In: E. Cavada, ed. Archeologia a Mezzocorona. Documenti per la storia del popolamento rustico di età romana nell'area atesina. Mezzocorona: Centro di Studi Rotaliani, pp. 233-46.

Riedel, A. \& Tecchiati, U. 1999. Settlements and Economy in the Bronze and Iron Age in Trentino-South Tyrol: Notes for an Archaeozoological Model. Preistoria Alpina, 35: 105-13.

Salač, V. (2005). Vom Oppidum zum Einzelgehöft und zurück - zur Geschichte und dem heutigen Stand der Latèneforschung in Böhmen und Mitteleuropa. Alt-Thüringen, 38: 279-300.

Sambraus, H. 1994. Atlas der Nutztierrassen. Stuttgart: Ulmer.

Schäffer, J. \& Steger, U. 1985. Zu neuen Tierknochenfunden aus dem Oppidum von Manching. Germania, 63: 57-73.

Schäffer, J. \& von den Driesch, A. 1983. Tierknochen aus fünf frühmittelalterlichen Siedlungen Altbayerns. Documenta naturae, 15: 1-78.

Schefzik, M. 2001. Die bronze- und eisenzeitliche Besiedlungsgeschichte der Münchner Schotterebene. Eine Untersuchung zu Gebäude- und Siedlungsformen im süddeutschen Raum. Rahden: Marie Leidorf.

Schmitzberger, M. 2007. Archäozoologische Untersuchungen an den bronze-, eisenund römerzeitlichen Tierknochen vom Ganglegg bei Schluderns und vom Tartscher Bichl. In: H. Steiner, ed. Die befestigte Siedlung am Ganglegg im Vinschgau/Südtirol. Bolzano: ${ }^{80 m i}$ Editrice, pp. 617-742.

Segard, M. 2009. Pastoralism, Rural Economy and Landscape Evolution in the Western Alps. Journal of Roman Archaeology, 22: 171-82.

Sieler, M. 2009. Die frübkaiserzeitlichen Holzbauten im Bereich der kleinen Thermen von Cambodunum-Kempten. Kallmünz: Lassleben.

Sievers, S. 2003. Manching - Die Keltenstadt. Stuttgart: Theiss.

Sommer, C. S. 2008. Die Anfänge der Provinz Raetien. In: I. Piso, ed. Die römischen Provinzen. Begriff und Gründung. Colloquium Cluj-Napoca, 28. September-1. Oktober 2006. Cluj-Napoca: Editura Mega, pp. 207-24. 
Staudt, M., Klocker, C., Flatscher, E. \& Stadler, H. 2014. KG Alkus, OG Ainet. Fundberichte aus Österreich, 52: 350-51.

Steidl, B. 2013. Die Augenfibel Almgren 4546 in Raetien und den Nordwestprovinzen. Eine Sachform als Spiegel historischer Vorgänge? In: G. Grabherr, B. Kainrath \& T. Schierl, eds. Verwandte in der Fremde? Akten des Internationalen Kolloquiums Innsbruck 27. bis 29. April 2011. Innsbruck: Innsbruck University Press, pp. 154-75.

Steidl, B. \& Will, M. 2005. Römer und Bajuwaren - Ausgrabungen auf der Trasse der A 99, Autobahnring MünchenWest. Das archäologische Jahr in Bayern, 25: 113-16.

Steiner, H. 2010 ed. Alpine Brandopferplätze. Archäologische und naturwissenschaftliche Untersuchungen. Trento: Editrice Temi.

Stöckli, W. 1979. Die Grob- und Importkeramik von Manching. Wiesbaden: Steiner.

Stopp, B. 2011. Archäozoologische Auswertung der Grabungen FH 1978/13 und TEW 1978/26 auf dem Basler Münsterhügel. In: E. Deschler-Erb, ed. Der Basler Münsterbügel am Übergang von spätkeltischer zu römischer Zeit.. Basel: Archäologische Bodenforschung des Kantons Basel-Stadt, pp. 237-62.

Tecchiati, U. 2006. La fauna del II-I secolo a. C. di San Giorgio di Valpolicella - via Conca d'Oro (VR). In: U. Tecchiati \& B. Sala, eds. Archaeozoological Studies in Honour of Alfredo Riedel. Bolzano: Ufficio Beni Archeologici, pp. 181-216.

Tecchiati, U. 2012. Die Tierknochen der bronze- und eisenzeitlichen Siedlung auf dem Kiachbichl bei Faggen (Tirol, Österreich). Annalen des Naturbistorischen Museums Wien Serie A, 114: 21-78.

Tecchiati, U. \& Salvagno, L. 2013. Resti faunistici del IV-II sec. a. C. provenienti dal sito di Urtijë/St. Ulrich/Ortisei, Ciamp da Mauriz. Ladinia, 37: 15-93.

Uenze, H. 1971. Oppidum "FentbachSchanze". In: H. Dannheimer, ed. Miesbach - Tegernsee - Bad Tölz Wolfratshausen - Bad Aibling. Mainz: von Zabern, pp. 199-206.

Ulbert, G. 1959. Die römischen Donau-Kastelle Aislingen und Burghöfe. Berlin: Mann.

Ulbert, G. 1965. Der Lorenzberg bei Epfach. Die frübrömische Militärstation. München: Beck.
Ulbert, G. \& Zanier, W. 1997. Der Auerberg II. Besiedlung innerbalb der Wälle. München: Beck.

Volpert, H.-P. \& Früchtl, S. 2012. Römische Holzbaubefunde des 1. Jahrhunderts n. Chr. im Gewerbegebiet "Hasenheide Nord" in Fürstenfeldbruck. Das archäologische Jahr in Bayern, 27: 77-79.

von den Driesch, A. 1984. Tierknochenfunde aus der spätkeltischen Siedlung von Berching-Pollanten, Ldkr. Neumark/ Oberpfalz. Germania, 62: 364-72.

von den Driesch, A. 1994. Tierknochenfunde vom Auerberg. In: G. Ulbert, ed. Der Auerberg I. Topographie, Forschungsgeschichte und Wallgrabungen. München: Beck, pp. 213-30.

von den Driesch, A. 1995. Die Tierknochen. In: S. Rieckhoff, Süddeutschland im Spannungsfeld von Kelten, Germanen und Römern. Studien zur Chronologie der Spätlatènezeit im südlichen Mitteleuropa. Trier: Rheinisches Landesmuseum Trier, pp. 263-64.

von den Driesch, A. \& Kruszona, W. 2005. Zoologische Bestimmung der Tierknochenfunde aus der Viereckschanze 2 von Holzhausen. In: K. Schwarz \& G. Wieland, eds. Die Ausgrabungen in der Viereckschanze 2 von Holzhausen. Rahden: Marie Leidorf, pp. 93-114.

Wells, P. ed. 1993. Settlement, Economy and Cultural Change at the End of the European Iron Age: Excavations at Kelheim, Bavaria, 1987-1991. Ann Arbor (MI): International Monographs in Prehistory.

Werner, P. 1981. Almen. Bäuerliches Wirtschaftsleben in der Gebirgsregion. München: Callwey.

Wickham, H. 2009. ggplot2: Elegant Graphics for Data Analysis. New York: Springer.

Wieland, G. ed. 1999. Keltische Viereckschanzen einem Rätsel auf der Spur. Stuttgart: Theiss.

Zanier, W. 1999. Der spätlatène- und römerzeitliche Brandopferplatz im Forggensee (Gde. Schwangau). München: Beck.

Zanier, W. 2010. Der römische Alpenfeldzug unter Tiberius und Drusus im Jahre 15 v. Chr. Übersicht zu den historischen und archäologischen Quellen. In: R. Aßkamp \& T. Esch, eds. IMPERIUM Varus und seine Zeit. Beiträge zum internationalen Kolloquium des LWLRömermuseums am 28. und 29. April 2008 in Münster. Münster: Aschendorff, pp. 73-96. 


\section{Biographical Notes}

Simon Trixl is a research assistant at the Institute of Palaeoanatomy, Domestication Research, and the History of Veterinary Medicine and a $\mathrm{PhD}$ student at the Institute of Pre- and Protohistory and the Archaeology of the Roman Provinces at the Ludwig Maximilian University Munich. His main research concerns the development of animal husbandry in metal age and Roman central Europe, with special emphasis on the transitional phase between the Iron Age and the Roman period.

Address: Institute of Palaeoanatomy, Domestication Research and the History of Veterinary Medicine and ArchaeoBioCenter, LMU Munich, Kaulbachstr. 37, 80539 Munich, Germany. [email: simon.trixl@ palaeo.vetmed.uni-muenchen.de]

Bernd Steidl heads the Roman department of the Archäologische Staatssammlung in Munich. His work focuses on the Roman provinces of Germania, Raetia, and Noricum with special regard to history of local populations as well as Roman-Germanic interaction on the external frontier (limes).
Address: Bavarian State Archaeological Collection, Lerchenfeldstr. 2, 80538 Munich, Germany. [email: Bernd.Steidl@ extern.lrz-muenchen.de]

Joris Peters is professor and chair of the Institute of Palaeoanatomy, Domestication Research, and the History of Veterinary Medicine at the Ludwig Maximilian University Munich and Director of the State Collection of Anthropology and Palaeoanatomy, Munich. He specializes in Old World archaeozoology, with a focus on the transition from hunting to animal husbandry in the Fertile Crescent and the cultural history of domestic animals.

Address: Institute of Palaeoanatomy, Domestication Research and the History of Veterinary Medicine and ArchaeoBioCenter, LMU Munich, Kaulbachstr. 37, 80539 Munich, and Bavarian State Collection for Anthropology and Palaeoanatomy, Karolinenplatz 2a, 80333 Munich, Germany. [email: joris.peters@palaeo. vetmed.uni-muenchen.de]

\section{Archéologie et archéozoologie à l'époque de transition entre l'âge du Fer et l'ère romaine dans la province de Rhétie (100 av. J.-C. à 100 apr. J.C.)}

L'intégration dans l'empire romain de la région au nord des Alpes et de son avant-pays a entraîné des changements profonds dans l'économie et la structure sociale ainsi que dans le quotidien de la nouvelle province de Rhétie. Mais le débat règne sur les questions de continuité des traditions locales de La Tène au début de l'époque romaine; en effet les données archéologiques relevées jusqu'à présent donnent l'impression que l'avant-pays nord-alpin était essentiellement désert jusqu'à la conquête romaine en 15 av. J.-C. Cependant les fouilles en cours dans l'avant-pays nord-alpin augmentent progressivement la visibilité archéologique de cette phase de transition. Par rapport aux populations romaines provinciales installées aux abords des voies romaines telle la Via Claudia Augusta, certaines sociétés se démarquent par le caractère singulier de leur culture. C'est le cas du groupe de Heimstetten que l'on retrouve dans l'arrière-pays de la Rhétie orientale entre environ 30 et 60 apr. J.-C. Son architecture, l'organisation de l'habitat et ses rites funéraires sont proches de la culture de La Tène, ce qui indiquerait une certaine continuité dans le milieu indigène au début de l'occupation romaine. Etant donné que les ossements d'animaux peuvent servir de marqueurs culturels, l'analyse chrono-géographique de la composition des troupeaux et des pratiques d'élevage permet d'approfondir nos connaissances. Les résultats que nous 
présentons ici démontrent que des différences régionales importantes dans la composition des espèces existaient à l'âge du Fer, ce qui sous-entend que les différentes régions auraient également pu évoluer différemment au début de l'époque romaine. En plus de l'examen de l'évolution des animaux domestique dans l'aire d'étude entre environ 100 av. J.-C. et 100 apr. J.C, nous abordons aussi la question de l'élevage des bovins. Ces animaux, traditionnellement à la base de l'économie d'élevage dans nombre de régions mais surtout dans les basses-terres de Rhétie depuis l'âge du Bronze, font l'objet d'un examen plus approfondi.

Mots-clés: Rhétie, âge du Fer, transition de l'âge du Fer à l'époque romaine, groupe de Heimstetten, romanisation, composition des troupeaux, bovins

\section{Der Übergang von der späten Eisen- in die römische Kaiserzeit in der Provinz Raetien (ca. 100 v. Chr. bis 100 n. Chr.) aus archäologischer und archäozoologischer Perspektive}

Die Eingliederung des Alpenraumes und des nördlichen Alpenvorlandes in das Imperium Romanum bedeutete für das Gebiet der neugegründeten Provinz Raetien einschneidende Veränderungen der Wirtschafts- und Sozialstruktur sowie des Alltagslebens ihrer Bewohner. Eine kontroverse Diskussion wird allerdings über den Fortbestand latènezeitlicher Traditionsstränge in die frühe römischen Kaiserzeit geführt: So sprach der archäologische Forschungsstand lange dafür, dass das Alpenvorland zur Zeit der römischen Eroberung 15 v. Chr. weitgehend unbesiedelt gewesen sei. Grabungen jüngerer Zeit ist es jedoch zu verdanken, dass das Bild dieser Übergangsphase zunehmend an Schärfe gewinnt. Den provinzialrömischen Siedlern der frühen Kaiserzeit, wie sie entlang der Via Claudia Augusta und in deren Umgebung nachgewiesen sind, steht eine aus kultureller Sicht einzigartige Bevölkerung gegenüber: die Heimstettener Gruppe. Das Verbreitungsgebiet dieser zwischen ca. 30 und $60 \mathrm{n}$. Chr. bestehenden Gruppe liegt im Osten der Provinz Raetien. Hinsichtlich der Bautraditionen, Siedlungsstrukturen und Bestattungssitten weist sie enge Bezüge zur Latène-Kultur auf, woraus auf einen Fortbestand einheimischer Traditionen in die römische Kaiserzeit zu schließen ist. Da es sich auch bei Faunenresten aus archäologischen Kontexten um potenzielle kulturelle Marker handelt, kann auch die Analyse räumlich und zeitlich bedingter Unterschiede in der Zusammensetzung der Tierbestände sowie der Veränderung von Zuchtpraktiken einen Beitrag zu dieser Thematik leisten. Die hier vorgestellten Ergebnisse machen deutlich, dass bereits in der Eisenzeit augenfällige regionale Unterschiede in der Zusammensetzung der Archäofaunen bestanden, wodurch es zu verschiedenen Entwicklungen in der Frühphase der Romanisierung gekommen sein könnte. Neben den Veränderungen, welche die Haustierbestände des Untersuchungsgebietes zwischen 100 v. Chr. und 100 n. Chr. durchliefen, liegt ein besonderes Augenmerk auf der Rinderzucht, die in vielen Regionen und vor allem in der Münchner Schotterebene mindestens seit der Bronzezeit die Basis der Viehwirtschaft darstellte.

Stichworte: Raetien, Eisenzeit, Übergang der Späteisen- zur Römerzeit, Heimstettener Gruppe, Romanisierung, Viehbestand, Rind 